\title{
P04.40. Lifestyle therapy use in pediatric cancer survivors
}

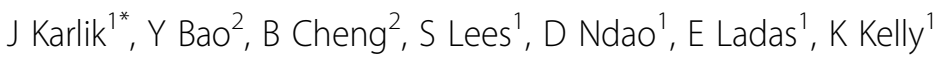 \\ From International Research Congress on Integrative Medicine and Health 2012 \\ Portland, Oregon, USA. 15-18 May 2012
}

\section{Purpose}

Pediatric cancer survivors often experience late effects secondary to cancer therapy, but their choices for symptom management is largely unknown. Many of these late effects can be treated by lifestyle changes such as diet, exercise, and conventional supplements. Although the use of lifestyle therapies appears common in children and adolescents, including pediatric cancer survivors, the reasons for use and perceptions of efficacy have not been investigated.

\section{Methods}

We report the results of a cross sectional survey investigating the prevalence of lifestyle therapy use, types and reasons for lifestyle therapy use, and determinants of lifestyle therapy use among survivors of childhood cancer.

\section{Results}

One hundred fifty-five (95\%) patients approached in person and $45(34 \%)$ patients approached by mail consented to participate in the study. Twenty-four participants participated in an original survey and were longitudinally followed with a repeat survey approximately 10 years later. Average age of participants was $14.5 \pm 6.2$ years. The average time from completion of cancer treatment to survey administration was $4.5 \pm 4.0$ years. One hundred thirty-four (68\%) made lifestyle modifications overall; $46 \%$ took multivitamin or conventional supplements, $45 \%$ used dietary changes, and $21 \%$ used exercise. Reasons for use included general health $(87 \%)$ and specific symptoms/side effects (13\%). Of specific reasons, general health and healing (31\%) and fitness/weight control (25\%) were common. Sixty-one percent of participants thought their lifestyle change was very effective and 25\%

${ }^{1}$ Columbia University Medical Center, Dept of Pediatric Oncology, New York City, USA

Full list of author information is available at the end of the article thought it was somewhat effective. Forty-three percent obtained lifestyle information from a family member/ friend and 29\% obtained information from their physician. Eighty-five percent of survivors disclosed the use of lifestyle modifications to their physician.

\section{Conclusion}

Many pediatric cancer survivors use lifestyle therapies and believe that these changes are effective. Given the widespread use of lifestyle therapies in pediatric cancer survivors, research is needed on the efficacy of lifestyle modifications in treating symptoms/side effects and improving general health of pediatric cancer survivors.

\section{Author details}

${ }^{1}$ Columbia University Medical Center, Dept of Pediatric Oncology, New York City, USA. ${ }^{2}$ Columbia University Medical Center, New York City, USA.

Published: 12 June 2012

doi:10.1186/1472-6882-12-S1-P310

Cite this article as: Karlik et al.: P04.40. Lifestyle therapy use in pediatric cancer survivors. BMC Complementary and Alternative Medicine 201212

(Suppl 1):P310.

Submit your next manuscript to BioMed Central and take full advantage of:

- Convenient online submission

- Thorough peer review

- No space constraints or color figure charges

- Immediate publication on acceptance

- Inclusion in PubMed, CAS, Scopus and Google Scholar

- Research which is freely available for redistribution
C Biomed Central

() 2012 Karlik et al; licensee BioMed Central Ltd. This is an Open Access article distributed under the terms of the Creative Commons Attribution License (http://creativecommons.org/licenses/by/2.0), which permits unrestricted use, distribution, and reproduction in any medium, provided the original work is properly cited. 